Yaroslav Y. Kulkov, Sultan S. Sadykov,

DOI: 10.25045/jpit.v11.i1.02

Arcady L. Zhiznyakov, Denis G. Privezentsev

Murom Institute of Vladimir State University, Murom, Russia

y_mail@mail.ru

\title{
CLASSIFICATION OF INDIVIDUAL FLAT OBJECTS BY THE FOREL METHOD
}

\author{
Received: 25.01.2019 \\ Revised: 28.03.2019 \\ Accepted: 26.06.2019
}

\begin{abstract}
With the growth of production automation, it became necessary to ensure the operation of many technological processes without human participation. These are mainly the processes associated with routine, repetitive work or dangerous to humans. Such processes include the classification of objects. Vision systems can be used to solve this problem. Today, visual control systems are widely in demand in various fields of science, industry and technology. In particular, they are used to obtain data on monitoring the state of objects, their location, and recognizing any objects of different forms. In this paper, it is proposed to test the applicability of the FOREL clustering algorithms for solving the problem of classifying individual flat objects based on their dimensionless features. The result of the work will be the probabilities of recognition of each object from a given test sample, on the basis of which it will be possible to draw a conclusion about the applicability of this method for solving the formulated problem.
\end{abstract}

Keywords: FOREL, FOREL2, clustering, identification, dimensionless features.

\section{Introducion}

Automation of the process, including with the help of robotic systems, is one of the ways to improve the production efficiency. The rapid development of high technology gave impetus to the widespread use of complex computing technology in production.

The task of the recognizing the objects in images is one of the most relevant tasks. The problem of parts recognition is not completely solved, the sorting and assembly processes are automated in production [1-3].

The quality of recognition often depends on the effectiveness of a variety of processes, starting from the image processing process, the formation of object features and ending on the choice of a method for classifying the objects on the basis of formed features $[4,5]$. In this paper, it is proposed to elaborate the selection of a recognition method, namely, testing the operation of the FOREL2 algorithm.

This algorithm refers to clustering algorithms. The FOREL2 algorithm divides the total sample space into taxa (clusters). The essence of the algorithm lies in the fact that the vectors of signs that are close to each other and have similar characteristics should be assembled into one cluster.

FOREL2 is a modification of the original FOREL algorithm and is used in the cases when it is necessary to obtain the initially specified number of clusters (taxons) [6, 7]. The use of this algorithm will allow to increase the speed of recognition compared to the method of the nearest neighbor. It is proposed to develop a program that recognizes objects using the FOREL2 method, calculate the recognition probabilities and conclude that it is expedient to use this algorithm to solve recognition problems.

The ways to extract the base and the formation of dimensionless signs of flat objects along their convex hull are given in $[3,5,8]$. A distinctive feature of the applied dimensionless marks is that they are invariant to the rotation, transfer and change of the scale of objects in the field of view of recognition system.

\section{Formulation of the problem}

The solution of the problem of recognizing an object in an image is often reduced to three main stages: preliminary processing of the image, formation of the feature vector, and recognition of the object by the selected method. 
The use of a single feature for recognizing the flat parts and products creates considerable difficulties in selecting etalons and adjusting the video sensor, since the curvature of a discrete line, such as contour, is not invariant to change the scale of the objects in the field of view of the vison system.

Since in this paper it is decided to elaborate on the third stage in more detail, the input data will be the already formed feature vectors for each of the ten test sample objects. The set of signs includes 19 values formed on the convex hull of the object $[3,8,9]$.

The result of the algorithm will be a set of formed clusters each of which will contain the feature vectors of classified objects. After the clusters are obtained, it will be necessary to analyze the result and calculate the number of errors in each of them in order to calculate the probability of recognition of one or another object.

\section{Solution Method}

Since the recognition of the objects is assumed based on the parameters generated along the convex hull of the binary image, this allows us to exclude from the analysis the internal points of the image and thereby significantly reduce the amount of information processed.

The technology of carrying out the experiments for calculating dimensionless signs from the convex hulls of binary images of individual flat objects, and their recognition includes the following sequence of procedures:

1) image pre-processing;

2) obtaining the contour of the binary image of the object;

3) construction of its convex hull;

4) formation of a database of signs;

5) learning the recognition system;

6) recognition.

Pre-processing is carried out in order to suppress the noise that occurs in the image at the stage of their registration with a video camera. The task of pre-processing is to effectively reduce the noise while maintaining the important elements for subsequent recognition of image elements. The output of this stage is the image of a real object on a white background.

To implement the task of identification, it is decided to consistently use FOREL algorithms and its FOREL2 modification. At the first stage, the FOREL algorithm splits the total test sample into a certain number of taxons (clusters) [6,7]. At the next stage, the FOREL2 algorithm already works with the obtained set of clusters until it is possible to obtain their required number (in this case, 10 objects).

The first step of the FOREL algorithm is the calculation of the hypersphere radius, in which all the objects of the test sample fall. To do this, we must initially find the maximum distance between the formed feature vectors. To calculate the distance between the vectors, the metric of the square of the Euclidean distance (1) is used. Other metrics such as Euclidean distance, Standard deviation include more actions, but do not affect the result:

$$
d(p, q)=\sqrt{\sum_{k=1}^{n}\left(p_{k}-q_{k}\right)^{2}}
$$

where $d(p, q)$ - Euclidean square distance, $p_{k}$ - current element of the first vector of signs, $q_{k}$ - current element of the second vector of signs.

To calculate the initial radius of a region, the following formula (2) is used.

$$
R=d(p, q) / 2 \text {, }
$$

where $R$-cluster area radius, $d(p, q)$ - maximum distance between the objects of one cluster.

Then it is needed to gradually reduce the radius of the sphere. The radius $\mathrm{R} * 0.9$ is taken and the center of the sphere is transferred to one of the points (vectors) inside it. The number of vectors is calculated, the distance to which is less than the selected radius and the center of gravity is calculated 
for these vectors. The next step is to transfer the center of the sphere to the resulting center of gravity, and then re-calculate the number of vectors in it. The sphere floats towards the local concentration of points. The described set of actions is repeated until the sphere ceases to move. This means that the sphere has stopped in the region of the local maximum of the density of vectors in the attribute space.

The vectors that are inside the stopped sphere are declared to belong to the cluster for the first object and are excluded from the test set. For the remaining vectors, the procedure described above is repeated until all of them are included in taxa (clusters).

After the initial set of clusters is obtained, it is necessary to use the FOREL2 algorithm. This is a modification of the FOREL algorithm which is used to obtain the required number of clusters. In this method, it is necessary to change the radius of the sphere to a certain value which decreases at each new step of the algorithm (it is chosen experimentally). Such approach of successive approximations allows to quickly approach a given number of taxons with the minimum possible radius of the spheres. The result of the algorithm becomes a set of 10 taxa for each object which contain similar vectors of signs.

\section{Implementation of the results}

The details that are located in the field of view and have arbitrary orientations are subject to recognition. The background on which images of details are recorded can be considered uniform, and the lighting conditions can be considered non-shadow.

During the experimental research, the random appearance of the objects in the field of a vision system with their random arrangement was simulated.

The filtering of the halftone image noise of real flat objects is carried out using a $3 \times 3$ point median filter. The QuickHull method is used to form the convex hulls.

To test the efficiency of the algorithm, a test sample of 20,000 vectors is compiled (10 classes of objects with 2000 vectors). For research, we used the images of 10 different details, depicted in figure 1 . For the formation of such a set of vectors, 10 real flat objects are selected. Then, by turning and scaling operations, 2000 images of each object are obtained. Each of the obtained images underwent preliminary processing after which the convex hull of the object is constructed.

The QuickHull algorithm is based on a recursive detour of the points of the set $S$ with excluding some points from consideration $[3,5]$. This means that most of the points in the image will not be considered at all.

The first step of the algorithm is to find the leftmost and rightmost points of the set of image points. Break the initial set by a line passing through the found points to the "upper" set and the "lower" one. Then, for each of the sets obtained separately, the algorithm is repeated.

The algorithm is executed recursively, receiving at the input a set of points and extreme points. Next, it is checked whether the resulting set is empty. If so, the recursive call is completed, and the resulting stack of points will contain the points related to the convex hull of the subset.

On the algorithm given in $[3,5,8]$, primary marks are calculated on the basis of the received convex hulls. Treat those: convex hull $\mathrm{P}_{0}$ perimeter length; area of the image $\mathrm{S}_{0}$; quantity of points, with curvature of $+90\left(\mathrm{M}_{1}\right),-90\left(\mathrm{M}_{2}\right),+135\left(\mathrm{M}_{3}\right)$ and -135 $\left(\mathrm{M}_{4}\right)$ degrees; metric length of a contour of $\mathrm{L}_{\text {kont. }}$; total length of convex $\mathrm{L}_{\text {tot.Vyp. }}$, concave $\mathrm{L}_{\text {tot.Vog. }}$ and linear $\mathrm{L}_{\text {tot.Lin. }}$ sites of all contour; quantity of 4 coherent points of a contour K; quantity of the coherent points $\mathrm{D}$ of a contour of T.

The dimensionless signs are formed on the basis of the received primary signs vectors, as given in $[3,5,8]$.

On the basis of the convex hulls, a set of 20,000 vectors of dimensionless signs of objects is obtained.

The program, receiving the input data a set of trait vectors, conducts clustering by the FOREL2 method and returned 10 clusters. Then, in each of the obtained clusters, the number of valid vectors and the number of errors are calculated, on the basis of which it is possible to find the probability of recognition of each object. 
The algorithms of the FOREL family are dependent on the random vectors chosen at the next iteration during cluster formation. The choice of these vectors directly affects the result of clustering. Therefore, in order to get more complete picture of the operation of the algorithm, 10 tests are carried out.

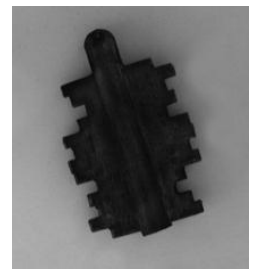

Object 1

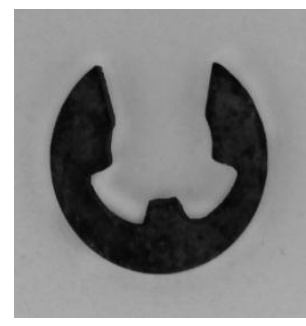

Object 6

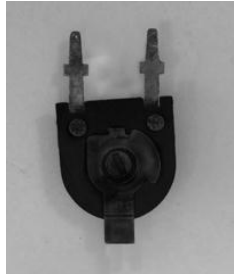

Object 2

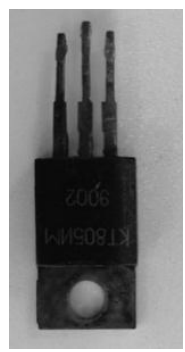

Object 7

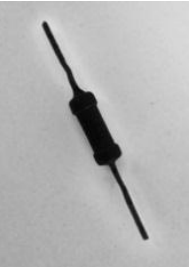

Object 3

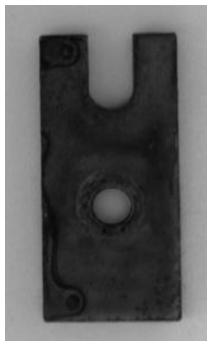

Object 8

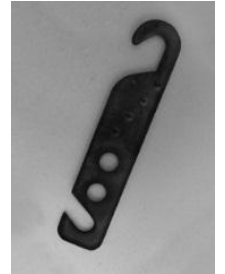

Object 4

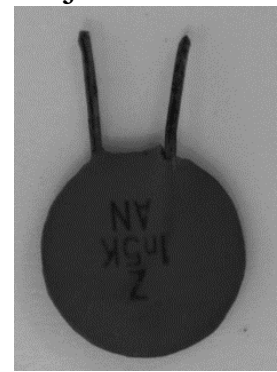

Object 9

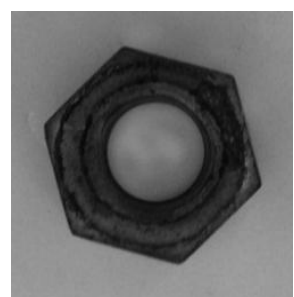

Object 5

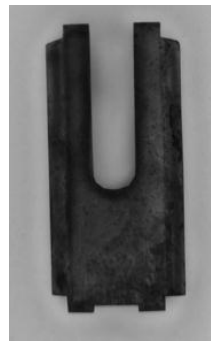

Object 10

Figure 1. Example of images of real object

The results of these tests are shown in table 1. The graph of the average probability of recognition of each of the objects is shown in figure 1 .

Table 1

The results of the experiments

\begin{tabular}{|c|c|c|c|c|c|c|c|c|c|c|c|}
\hline \multicolumn{2}{|c|}{ Class number } & 1 & 2 & 3 & 4 & 5 & 6 & 7 & 8 & 9 & 10 \\
\hline \multirow{10}{*}{ 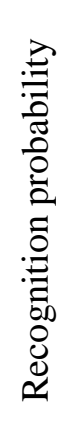 } & Exp. 1 & 0.9 & 0.57 & 1 & 0.52 & 1 & 1 & 1 & 1 & 0.53 & 0.88 \\
\hline & Exp. 2 & 1 & 0.93 & 1 & 0.53 & 1 & 1 & 1 & 1 & 0.97 & 0.52 \\
\hline & Exp. 3 & 1 & 0.63 & 1 & 0.85 & 1 & 1 & 1 & 1 & 0.44 & 0.5 \\
\hline & Exp. 4 & 0.88 & 0.43 & 1 & 0.38 & 1 & 1 & 1 & 1 & 1 & 1 \\
\hline & Exp. 5 & 0.38 & 0.67 & 1 & 0.9 & 1 & 1 & 1 & 1 & 0.51 & 0.74 \\
\hline & Exp. 6 & 0.33 & 0.97 & 1 & 0.75 & 1 & 1 & 1 & 1 & 0.49 & 0.9 \\
\hline & Exp. 7 & 0.69 & 0.64 & 1 & 0.78 & 1 & 1 & 1 & 1 & 0.56 & 0.66 \\
\hline & Exp. 8 & 0.42 & 0.48 & 1 & 0.89 & 1 & 1 & 1 & 1 & 0.86 & 1 \\
\hline & Exp. 9 & 0.43 & 0.51 & 1 & 0.5 & 1 & 1 & 1 & 1 & 0.7 & 0.73 \\
\hline & Exp. 10 & 0.92 & 0.17 & 1 & 0.5 & 1 & 1 & 1 & 1 & 0.66 & 0.84 \\
\hline
\end{tabular}

Recognition probability

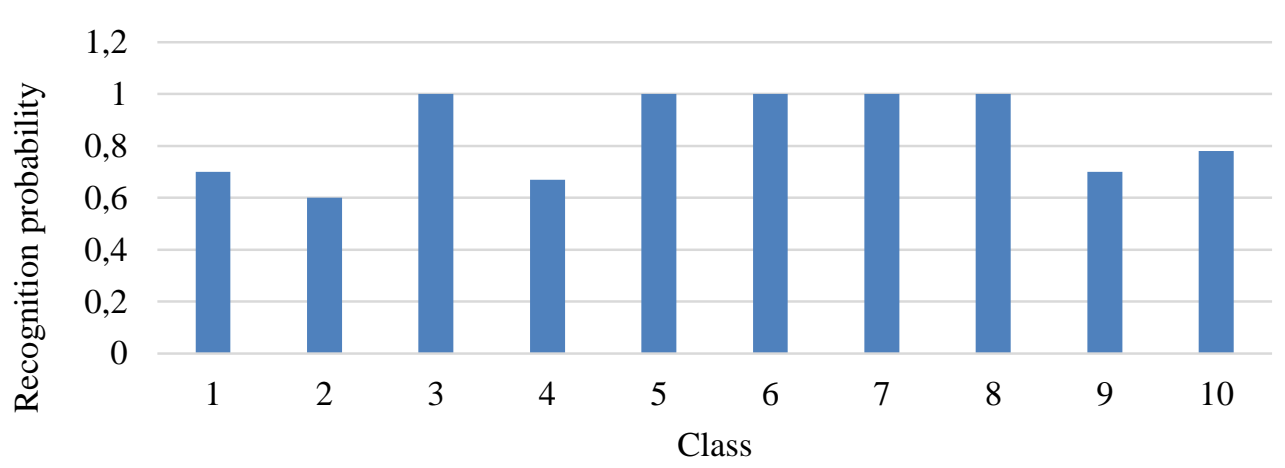

Figure 2. Recognition probability 


\section{Conclusion}

The used recognition method did not allow for the complete identification of the entire set of objects. Depending on the complexity of the contours of the objects and the calculated convex shells used to generate various classes, a different number of standards was required at the stage of cluster formation.

According to the results presented in Table 1, the 5 classes were classified correctly $(3,5-$ 8 ). This suggests that there was not much variation between the vectors of this class. The remaining five classes, depending on the experiment, had a slight variation between the two probability indicators: either it turned out to be high (0.89) or medium $(0.48)$.

Figure 2 showed the average probability of recognition of each of the classes. The minimum probability obtained as a result of the experiment was $60 \%$ (class number 2). Three more classes (1.4.9) were located between $65-70 \%$. Class 10 had a recognition probability of almost $78 \%$, the other five classes were recognized without errors.

For further recognition, the FOREL2 algorithm can be used as follows: calculate the centers of each of the 10 clusters obtained and compare them with the new incoming object for recognition. Based on this, it is possible to calculate the time for recognizing one object.

The average recognition time for one object was $613 \mathrm{~ms}$, taking into account the reading of cluster centers from the base $(73 \mathrm{~ms}$, if we consider only image processing, the calculation of the vector of signs and classification). The greatest time was spent on an iterative algorithm for the formation of a convex shape. Mask scanning could be optimized by traversing only the contour. Thus, it was possible to significantly reduce the operating time of the entire algorithm for the formation of dimensionless features along a convex hull of an image.

The low probability of recognition of some classes may be due to several factors:

- class vectors have a small distance to the vectors of another class;

- class vectors have a strong variation within their class.

For these reasons, the FOREL2 algorithm, which dependad on a newly selected random vector at the next stage of its work, could show both the high probability of classification for the objects of such classes and the average. At the same time, as a result of the experiments, the classes with a classification probability equal to 1 were obtained. This suggested that FOREL2 algorithm, which was more distinct from the general sample, could classify correctly.

Thus, in this work, the system of recognition of the vectors of dimensionless signs was implemented by the FOREL 2 method and the quality of the algorithm and its applicability to solve the problem was analyzed.

During the analysis of the algorithm, both disadvantages and advantages in this work were identified. The advantages of the method included a high recognition rate. The disadvantages of the method were rather low probability of recognizing some objects and its dependence on the choice of initial vectors during clustering.

In the future, we plan to analyze other algorithms in order to select the most optimal one for solving the problem of recognition of flat objects.

The reported study was funded by RFBR according to the research project №18-07-01191.

\section{References}

1. Genkin V.L, Moskalev E.S. Recognition systems for automated production / V.L.Genkin, I.L.Erosh, L.: Mashinostroenie, Leningradskoe otdelenie, 1988, 246 p.

2. Panov S.S., Mazepin P.G., Smirnov V.A., Petrova L.N. Robotic assembly stands with technical vision and computer control systems // Assembly in mechanical engineering, instrument making, 2010, no 12., pp. 23-28.

3. Sadykov S.S., Kulkov Y.Y. Recognition of individual test and real flat objects based on the dimensionless marks of convex hulls // Telecommunication. 2017, no 3. pp. 28-35.

4. Zagoruyko N.G., Lbov G.S., Elkin N.V. Empirical patterns detection algorithms. Novosibirsk: 
Nauka, 1985, $112 \mathrm{p}$.

5. Sadykov S.S., Kulkov Y.Y. The study of the possibility of recognizing flat objects using the dimensionless marks of the convex hulls of their two-gradation images // Proceedings of the international symposium "Reliability and quality", 2017, pp.76-79.

6. Amsharuk E.I., Gorbachev T.F. FOREL digital image clustering // Kuzbass State University, 2014, $350 \mathrm{p}$.

7. Schekin V.P., Cherniy S.G., Borduk A.S. Adaptive fuzzy systems on forel class taxonomy // Software products and systems, 2014, $115 \mathrm{p}$.

8. Sadykov S.S., Kulkov Y.Y. Recognition of Flat Objects Based on Dimensionless Marks Based of Their Contours [Text] // CEUR Workshop Proceedings, 2017, vol.1940, pp.68-73.

9. Sadykov S.S., Kulkov Y.Y. Recognition of individual test and real flat objects based on the dimensionless marks of the contours of their binary images // Information Technology, 2016. vol 22, no 10, pp.747-753.

\section{UOT 004.021}

Kulkov Yaroslav Y., Sadıkov Sultan S., Jiznyakov Arkadi L., Privezentsev Denis Q.

Vladimir Dövlət Universitetinin Murom filial1, Murom, Rusiya

y_mail@mail.ru

\section{FOREL metodları vasitəsilə ayrı-ayrı müstəvi obyektlərin təsnifatı}

İstehsalın avtomatlaşdırması sahəsinin genişlənməsi ilə insan iştirakı olmadan bir çox texnoloji proseslərin işinin təmin edilməsi zərurəti yaranmışdır. Bu proseslər əsasən adi, monoton işlərlə bağlı olan və ya insan üçün təhlükəli olan proseslərdir. Belə proseslərə obyektlərin təsnifatını misal göstərmək olar. Bu problemin həlli üçün texniki görmə sistemlərindən istifadə edilə bilər. Hazırda elm, sənaye və texnikanın müxtəlif sahələrində vizual nəzarət sistemlərinə böyük tələbat yaranmışdır. Onlar əsasən obyektlərin vəziyyətinə nəzarət, onların yeri, müxtəlif formalı istənilən obyektin tanınması haqqında məlumatların əldə edilməsi üçün istifadə olunur. Məqalədə ayrı-ayrı müstəvi obyektlərin ölçüsüz əlamətləri əsasında onların təsnifatı məsələsinin həlli üçün FOREL ailəsinin klasterizasiyası alqoritmlərinin tətbiqinin mümkünlüyünün yoxlanılması təklif edilmişdir. Verilmiş test seçməsindən olan hər bir obyektin tanınma ehtimalları tədqiqat işinin nəticəsi qismində təqdim edilmişdir. Bunun əsasında verilmiş məsələnin həlli üçün bu metodun tətbiq edilib-edilə bilməməsi haqqında nəticə çıxarmaq mümkün olacaqdır.

Açar sözlar: FOREL, FOREL2, obyektlarin tasnifatı, ölçüsüz alamətlar.

\section{УДК 004.021}

Кульков Ярослав Ю., Садыков Султан С., Жизняков Аркадий Л., Привезенцев Денис Г. Муромский филиал Владимирского государственного университета, Муром, Россия

y_mail@mail.ru

\section{Классификация отдельных плоских объектов методами семейства FOREL}

С ростом автоматизации производства возникла необходимость обеспечить работу многих технологических процессов без участия человека. Главным образом это процессы, связанные с рутинной, однообразной работой или опасные для человека. К таким процессам можно отнести классификацию объектов. Для решения этой проблемы могут быть использованы системы технического зрения. На сегодняшний день системы визуального контроля широко востребованы в разных областях науки, промышленности и техники. В частности, они используются для получения данных о контроле состояния объектов, их местонахождении, распознавания любых объектов разных форм. В данной работе предлагается проверить применимость алгоритмов кластеризации семейства FOREL для решения задачи классификации отдельных плоских объектов на основе их безразмерных признаков. Результатом работы станут вероятности распознавания каждого объекта из заданной тестовой выборки, на основе которых можно будет сделать вывод о применимости данного метода для решения поставленной задачи.

Ключевые слова: FOREL, FOREL2, классификаџия объектов, безразмерные признаки. 